\title{
Zika: Defining the Public Health and Exposing its Vulnerabilities
}

\author{
Frederick M. Burkle, Jr., MD, MPH, DTM, FAAP, FACEP
}

$\mathrm{I}$ n the early 1970s I suggested that inherently all crisis events keep us honest by immediately "defining the public health and exposing its vulnerabilities". In 2016, Jeffrey Duchin's article offers a new perspective on preparedness for the emerging Zika virus outbreak, and once again exposes the lack of public health preparedness. ${ }^{2}$ It reminds us that we are again facing a major "groundhog" moment. ${ }^{3}$ The Zika virus threat reliably exposes the obvious: we are no more prepared today to address this global outbreak and its public health deficiencies than we were in the 1970s and even decades before that.

Duchin reminds us of the "significant gaps in core areas of public health system readiness," the "lack of strategic investment" and "dynamic and effective leadership." These sustained and chronic revelations are getting old and must frustrate the readership as much as it does me and Professor Duchin. We either don't learn or no one is listening! He calls for a robust "foundational public health capacity" at the community level defined by seven sensible recommendations. ${ }^{2}$ While it makes sense, we need to do more.

Preparedness planning has routinely ignored crucial community level operational challenges. This was emphatically revealed in 2006 during the SARS pandemic when preparedness activities were considered "polarized." While countries in the Asia-Pacific focused on a strategic vision to strengthen future preparedness capacity, the responsibilities for important operational planning gaps, weaknesses, and inconsistencies remained unclear. ${ }^{4}$ The Achilles heel proved to be the absence of local "ways to care for patients at home, the maintenance of essential services, and adequate operational procedures for key stakeholders." It was further emphasized during SARS in Canada that "virtually all health care operations, including public health, are undertaken only at the local or regional level...lacking was local establishment of a flexible and sustainable emergency management system." Similar complaints surfaced during the H1N1 swine flu pandemic, as it has done so in every outbreak since. Local public health preparedness matters.

While many of us applauded the International Health Regulations Treaty in 2007 that provided unprecedented historical level of global cooperation for pandemics, its underperformance was palpable especially in regards to the West Africa Ebola tragedy. We cannot deny that a strong and effective World Health Organization is crucial. ${ }^{6}$ An "empowered" and globally supported WHO under the IHR for public health coordination and leadership is absolute but as Checchi and colleagues emphatically note, this will only occur through radical reform requiring "major surgery."7 Failures will continue unabated if these responsibilities, actions and activities are not duplicated first at the local and regional levels.

We are constantly reminded that we exist today in a globalized world. Before 9/11, many countries were beginning to accept such a wider vision and the possibilities of what unprecedented collaborative and coordinated global partnerships might bring to their own public health. After 9/11, many of those same countries once again returned to unapologetic nationalism. This was supported by an emphasis, fostered by threatened world powers, which insisted that all outbreaks were first to be considered a security issue (bioterrorism) before they were called otherwise. Political interference and unbridled decision-making became the norm. ${ }^{8}$

Medical journals are beginning to review submissions focusing on the unique properties of the Zika virus itself such as microcephaly, Guillain-Barre syndrome, potential cases of sexual transmission, discussions whether birth control will be sanctioned by the Catholic Church, and the more politically sensitive debate over legal and safe abortion of pregnant women carrying the disease. As such, we may not immediately recognize the importance to North America of the severe shortages of medicine and hospital care capacity in Venezuela forcing the Zika infected population to flee across the border to Colombia, spreading the virus and worsening already strained relationships.

Do we have today the capacity to participate and address these emerging global problems that risk impacting us in North America tomorrow and soon after in the rest of the world? Each pandemic serves as a real world exercise on how to best participate and generate the global debate and decisions to protect the global good. Such decisions were made in the Ebola epidemic. 
After time and much debate and hesitation, real but uncomfortable triage decisions were made in West Africa that led to its control. No easy task but a necessary one.

I am pleased the first published paper in the anticipated Zika series for this journal focuses on preparedness in the United States, but wonder whether this portends that a wider scope of topics will soon surface simply because it has impacted the Americas and the United States early. Would the dialogue have been different if Ebola had begun in North America?

Health care providers today do see themselves less as nationalists and more as global citizens. While this thinking has changed the global landscape for those of us in health, at the same time the political decision-makers have dug themselves deeper into national agendas while ignoring global concerns. Remember, health professionals also serve as educators and advocates and have an added ethical and moral responsibility to clarify for those in political power who, too often, 'do not know what they don't know.'

\section{About the Author}

Senior International Public Policy Scholar, Woodrow Wilson International Center for Scholars, Washington, DC; and Harvard Humanitarian Initiative, 14 Story Street, $2^{\text {nd }}$ Floor, Cambridge, MA 02138. E-mail: fburkle@hsph.harvard.edu
Published online: March 8, 2016.

\section{REFERENCES}

1. Burkle FM Jr. Redefining the Public Health of Nations. Power point presentation. Center of Excellence in Disaster Management \& Humanitarian Assistance. Honolulu, Hawaii, 1993.

2. Duchin JS. United States Public Health Preparedness for Zika and other threats remains vulnerable [published online ahead of print]. Disaster Med Public Health Prep. doi: 10.1017/dmp.2016.26.

3. Burkle FM Jr. Is it Groundhog Day? Disaster Med Public Health Prep. 2014 Oct; $8(5): 377-8$.

4. Burkle FM Jr. Do pandemic preparedness planning systems ignore critical community- and local-level operational challenges? Disaster Med Public Health Prep. 2010 Mar;4(1):24-9.

5. Johnson MM, Bone EA, Predy GN. Taking care of the sick and scared: a local response in pandemic preparedness. Can J Public Health. 2005;96:412-414.

6. Burkle FM Jr. Global Health Security Demands a Strong International Health Regulations Treaty and Leadership From a Highly Resourced World Health Organization. Disaster Med Public Health Prep. 2015 Oct;9(5):568-80.

7. Checchi F, Waldman RJ, Roberts LF, Ager A, Asgary R, Benner MT, Blanchet K, Burnham G, d'Harcourt E, Leaning J, Massaquoi MB, Mills EJ, Moresky RT, Patel P, Roberts B, Toole MJ, Woodruff B, Zwi AB. World Health Organization and emergency health: if not now, when? BMJ. 2016 Jan 28;352:i469.

8. Burkle FM Jr, Hanfling D. Political Leadership in the Time of Crises: Primum non Nocere. PLoS Curr. 2015 May 29;7. 